University of Nebraska - Lincoln

DigitalCommons@University of Nebraska - Lincoln

Faculty Papers and Publications in Animal

Science

Animal Science Department

2010

\title{
Tympanic temperature in confined beef cattle exposed to excessive heat load
}

\author{
Terry L. Mader \\ University of Nebraska - Lincoln, tmader1@unl.edu \\ John B. Gaughan \\ University of Queensland, j.gaughan@uq.edu.au \\ Leslie J. Johnson \\ University of Nebraska-Lincoln, ljohnson13@Unl.edu \\ G. Leroy Hahn \\ USDA ARS, MARC, hahn@email.marc.usda.gov
}

Follow this and additional works at: https://digitalcommons.unl.edu/animalscifacpub

Part of the Genetics and Genomics Commons, and the Meat Science Commons

Mader, Terry L.; Gaughan, John B.; Johnson, Leslie J.; and Hahn, G. Leroy, "Tympanic temperature in confined beef cattle exposed to excessive heat load" (2010). Faculty Papers and Publications in Animal Science. 1162.

https://digitalcommons.unl.edu/animalscifacpub/1162

This Article is brought to you for free and open access by the Animal Science Department at DigitalCommons@University of Nebraska - Lincoln. It has been accepted for inclusion in Faculty Papers and Publications in Animal Science by an authorized administrator of DigitalCommons@University of Nebraska Lincoln. 


\title{
Tympanic temperature in confined beef cattle exposed to excessive heat load
}

\author{
T. L. Mader • J. B. Gaughan • L. J. Johnson • \\ G. L. Hahn
}

Received: 26 November 2008 /Revised: 26 March 2009 / Accepted: 6 April 2009 /Published online: 30 April 2009

(C) ISB 2009

\begin{abstract}
Angus crossbred yearling steers $(n=168)$ were used to evaluate effects on performance and tympanic temperature (TT) of feeding additional potassium and sodium to steers exposed to excessive heat load (maximum daily ambient temperature exceeded $32^{\circ} \mathrm{C}$ for three consecutive days) during seasonal summer conditions. Steers were assigned one of four treatments: (1) control; (2) potassium supplemented (diet containing $2.10 \% \mathrm{KHCO}_{3}$ ); (3) sodium supplemented (diet containing $1.10 \% \mathrm{NaCl}$ ); or (4) potassium and sodium supplemented (diet containing 2.10\% $\mathrm{KHCO}_{3}$ and $1.10 \% \mathrm{NaCl}$ ). Overall, additional $\mathrm{KHCO}_{3}$ at the $2 \%$ level or $\mathrm{NaCl}$ at the $1 \%$ level did not improve performance or heat stress tolerance with these diet formulations. However, the addition of $\mathrm{KHCO}_{3}$ did enhance water intake. Independent of treatment effects, TT of cattle displaying high, moderate, or low levels of stress suggest that cattle that do not adequately cool down at night are prone to achieving greater body temperatures
\end{abstract}

Contribution of the University of Nebraska, Agricultural Research Division, Lincoln, NE 68583, USA

IJBM Special Issue - Honoring work of Leroy Hahn

T. L. Mader $(\bowtie) \cdot$ L. J. Johnson

Haskell Agricultural Laboratory, Department of Animal Science,

University of Nebraska,

57905866 Road,

Concord, NE 68728, USA

e-mail: tmader@unlnotes.unl.edu

J. B. Gaughan

School of Animal Studies, The University of Queensland,

Gatton,

QLD, Australia

G. L. Hahn

Environmental Management Research Unit,

U.S. Meat Animal Research Center, ARS-USDA,

Clay Center, NE, USA

U.S. government works are not subject to copyright. during a subsequent hot day. Cattle that are prone to get hot but can cool at night can keep average tympanic temperatures at or near those of cattle that tend to consistently maintain lower peak and mean body temperatures. In addition, during cooler and moderately hot periods, cattle change TT in a stair-step or incremental pattern, while under hot conditions, average TT of group-fed cattle moves in conjunction with ambient conditions, indicating that thermoregulatory mechanisms are at or near maximum physiological capacity.

Keywords Beef cattle $\cdot$ Body temperature $\cdot$ Diets . Environment $\cdot$ Heat stress

\section{Introduction}

Body temperature, when not influenced by physical activity, is a good measure of heat stress, and can be used effectively as a research and production tool to monitor not only cattle health but overall well-being (Mader et al. 2005). Certain feed additives containing high levels of electrolytes have shown promise for reducing internal body temperature (Kreikemeier et al. 2003). Sodium and potassium losses can occur in cattle via salivation, sweating, and/ or urination. In addition, sodium and potassium play important roles in maintaining osmotic pressure within cells, controlling the passage of nutrients into cells, and water metabolism. As ambient temperatures approach body temperatures, the amount of heat dissipated through sweating and increased urinary output are key physiological processes for maintaining body temperature. However, these excessive water and electrolyte losses increase plasma $\mathrm{pH}$ and bicarbonate concentration and reduce blood buffering capacity, impaired cellular function, and eventu- 
ally reduces heat stress coping ability (Sparke et al. 2001; Gaughan and Mader 2009).

Salt $(\mathrm{NaCl})$ is a common feed ingredient, which can be used to regulate feed intake, particularly at levels of $5 \%$ or more of the total diet dry matter; however, at levels up to $1 \%$, cattle tend to have an appetite for salt, which may stimulate intake (Gaughan and Mader 2009). Granzin and Gaughan (2002) found optimum milk yields in heatstressed dairy cows with dietary salt levels up to $2.2 \%$. In beef cattle, dietary potassium levels up to $1 \%$ were ineffective in mitigating the effects of mild heat stress (Doran et al. 1986). Spears and Harvey (1987) found potassium levels in the diet of $1.4 \%$ enhanced feed conversion when fed with $0.25 \%$ sodium. In transported calves, Hutcheson et al. (1984) found a significant reduction in mortality when diets contained between 1.3 and $2.2 \%$ potassium when compared with diets containing 0.7 or $3.2 \%$ potassium. The study reported herein was designed to evaluate the effect of moderate supplemental levels of sodium $(\mathrm{Na})$ and potassium $(\mathrm{K})$ in the diet on the ability of confined cattle to cope with excessive heat load. Dietary levels of $\mathrm{Na}(0.5 \%)$ and $\mathrm{K}(1.5 \%)$ were formulated to fall within the mid-range of levels fed in previously mentioned studies.

\section{Materials and methods}

Angus crossbred yearling steers $(n=180)$ were received at Haskell Agricultural Laboratory (near Concord, NE). Two days post-receiving, steers were weighed, implanted (Ralgro; Shering-Plough Animal Health, Kenilworth, NJ), vaccinated (Vision 7 and Titanium 5 PHM Bac 1; Intervet, Millsboro, DE), treated for external parasites (Saber; Schering-Plough Animal Health, Kenilworth, NJ), and ear tagged for individual identification. Upon trial initiation (50 days postreceiving), steers were implanted with Revalor-S (Intervet, Millsboro, DE). Average body weight, taken on two consecutive days, was used as the initial weight (mean $\mathrm{BW}=485 \mathrm{~kg}$ ). Based on the weight taken on the first day, 168 steers were stratified by weight, and assigned randomly to 1 of 24 pens (seven steers/pen).

Pens were blocked by location and assigned to one of four diet treatments: (1) control; (2) potassium (diet containing $2.10 \% \mathrm{KHCO}_{3}$ ); (3) sodium (diet containing $1.10 \% \mathrm{NaCl}$ ); or (4) potassium and sodium (diet containing $2.10 \% \mathrm{KHCO}_{3}$ and $1.10 \% \mathrm{NaCl}$ ). All diets were isocaloric (1.41 mcal ME/kg) and isonitrogenous $(13.4 \%$ crude protein) and contained dry rolled corn, alfalfa, corn silage and vitamin-mineral supplements (Table 1).

Feed and water intakes were recorded daily. Body weights were obtained on day 0,35 , and 67 (days before slaughter). Feed was delivered daily to each pen via a three-
Table 1 Diet composition, dry matter basis

\begin{tabular}{|c|c|c|c|c|}
\hline & \multicolumn{4}{|c|}{ Treatment $^{\mathrm{a}}$} \\
\hline & Control & $\mathrm{K}$ & $\mathrm{Na}$ & $\mathrm{KNa}$ \\
\hline \multicolumn{5}{|l|}{ Ingredient, $\%$} \\
\hline Alfalfa & 8.00 & 5.00 & 7.00 & 2.50 \\
\hline Corn silage & 4.50 & 4.50 & 4.0 & 7.00 \\
\hline Dry rolled corn ${ }^{\mathrm{b}}$ & 80.50 & 80.40 & 80.55 & 78.30 \\
\hline Dry supplement ${ }^{\mathrm{C}}$ & 2.00 & 2.00 & 2.00 & 2.00 \\
\hline Liquid supplement & 4.50 & 4.00 & 4.00 & 3.50 \\
\hline Soybean meal & 0.50 & 2.00 & 1.35 & 3.50 \\
\hline $\mathrm{KHCO}_{3}$ & - & 2.10 & - & 2.10 \\
\hline $\mathrm{NaCl}$ & - & - & 1.10 & 1.10 \\
\hline \multicolumn{5}{|c|}{ Estimated nutrient composition (NRC 1996) } \\
\hline Crude protein, $\%$ & 13.4 & 13.4 & 13.4 & 13.4 \\
\hline NEgain, mcal $/ \mathrm{kg}$ & 1.41 & 1.41 & 1.41 & 1.41 \\
\hline Potassium, \% & 0.75 & 1.54 & 0.73 & 1.53 \\
\hline Sodium, \% & 0.12 & 0.10 & 0.54 & 0.52 \\
\hline DCAD, meq/100 $\mathrm{g}^{\mathrm{d}}$ & 9.13 & 29.38 & 8.59 & 28.8 \\
\hline
\end{tabular}

${ }^{\mathrm{a}}$ Control $=$ control; $\mathrm{K}=$ potassium bicarbonate added to diet; $\mathrm{Na}=$ sodium chloride added to diet; $\mathrm{KNa}=$ potassium bicarbonate and sodium chloride added to diet

${ }^{\mathrm{b}}$ Contained on dry matter (DM) basis: $35.11 \%$ ground corn; $30.62 \%$ soybean hulls; $19.96 \%$ wheat midds; $4.21 \%$ molasses; $5.61 \%$ limestone; $3.10 \%$ soybean meal; $0.87 \%$ Rumensin $80(176.4 \mathrm{~g}$ monensin $/ \mathrm{kg}$; Elanco Animal Health, Indianapolis, IN); and $0.52 \%$ Tylan 40 (89 g tylosin/kg; Elanco Animal Health)

${ }^{\mathrm{c}}$ Contained on a DM basis: $61.54 \% \mathrm{CP} ; 12.30 \% \mathrm{Ca} ; 5.39 \%$ salt; $3.85 \% \mathrm{~K} ; 0.71 \% \mathrm{P} ; 0.43 \% \mathrm{Mg} ; 0.148 \% \mathrm{Zn} ; 0.037 \% \mathrm{Fe} ; 0.050 \% \mathrm{Mn}$; $0.021 \% \mathrm{Cu} ; 0.002 \% \mathrm{I} ; 0.001 \% \mathrm{Co} ; 6.6 \times 10^{4} \mathrm{IU} / \mathrm{kg}$ vitamin $\mathrm{A} ; 1.3 \times$ $10^{4} \mathrm{IU} / \mathrm{kg}$ vitamin $\mathrm{D}$; and $44 \mathrm{IU} / \mathrm{kg}$ vitamin $\mathrm{E}$

${ }^{\mathrm{d}} \mathrm{DCAD}=$ meq $(\%$ in diet/equivalent weight $)$ of $[(\mathrm{Na}+\mathrm{K})-(\mathrm{Cl}+\mathrm{S})]$

auger mixer (Oswalt Model 115; J-Star Industries, Fort Atkinson, WI), which was mounted on a feed truck equipped with electronic scales. Daily adjustments were made in feed delivery to maintain morning orts to between 0 and $2 \%$ of total feed delivered. Daily water intakes were determined from meter (Model C-700; ABB Water Meters, Box 1852, Ocala, FL) readings at the same time feed bunks were observed ( $\sim 0800$ hours). Tympanic temperatures (TT) were utilized as an indicator of body temperature and were recorded using Stowaway XTI data loggers and thermistors (Onset Corporation, Pocasset, MA). The thermistor was inserted into the ear canal until the tip reached the tympanic membrane. After thermistor insertion, the ear canal was sealed with cotton swabs to eliminate air exchange with the tympanic environment. The datalogger was then secured to the ear according to procedures previously outlined by Mader et al. (2002). Dataloggers recorded temperatures at 1-h intervals in 24 animals from eight pens ( 2 pens/ treatment; 3 animals/pen) during days 18-22 and 41-46 of 
the study. The same animals were used in both periods. Days 18-22 were designated as a thermoneutral (TNL) period, while days 41-46 were divided into two periods; moderately hot (MHOT: day 41-43) and hot (HOT: day 44-46). The hot period was based on categories outlined by Hahn and Mader (1997), in which 3-5 successive days with maximum temperatures above a threshold of $32^{\circ} \mathrm{C}$ is defined as a heat wave.

As a result of diet treatment outcomes, TT profiles were compared among animals that displayed high $\left(>41.7^{\circ} \mathrm{C}\right)$, moderate $\left(41.3\right.$ to $\left.41.7^{\circ} \mathrm{C}\right)$, and low $\left(<41.3^{\circ} \mathrm{C}\right)$ peak TT during the hottest day of the study. Previous studies (Mader et al. 1999; Davis et al. 2003; Mader and Kreikemeier 2006) have suggested that the range of daily TT may vary with the extent cattle are challenged by the heat event and that cattle may compensate (cool more at night if opportunities exist) by lowering TT to below normal TT levels after an excessive heat load event. An equal number of animals were utilized in the high, moderate, and low profile groups.

\section{Statistical analysis}

Performance data were analyzed using the mixed procedures of SAS (Statistical Analysis Service, Cary, NC). The model included potassium, sodium, and the potassium by sodium interaction. Tympanic temperatures for diet treatments among TNL, MHOT and HOT periods were analyzed using a repeated measures model that included sodium, potassium, time of day, period, and all possible interactions. The specified term for the repeated statement was animal within period. A subsequent and similar analysis was conducted for TT obtained only in the MHOT and HOT periods. Tympanic temperature across treatments and among groups of animals displaying low, moderate, and high TT, were analyzed using a repeated measures model that included TT group, day, time of day, and all possible interactions. The specified term for the repeated statement was animal within day.

\section{Results}

Over the entire study, no treatment differences were found for gain, feed intake, or feed efficiency (Table 2). The combined feeding of potassium and sodium tended to reduce $(P=0.09)$ overall average daily gain $(\mathrm{ADG})$, when compared to the other three treatments. However, daily water intake (DWI) was increased $(P<0.05)$ and DWI/dry matter intake $(\mathrm{DMI})$ ratio was increased $(P<0.05)$ when $\mathrm{KHCO}_{3}$ was added to the diet with DWI of control, $\mathrm{K}$, $\mathrm{Na}$, and $\mathrm{K}$ plus $\mathrm{Na}$ diets being $30.4,37.1,26.5$, and 38.0 1/day, respectively. Providing supplemental $\mathrm{Na}$, in the form of $\mathrm{NaCl}$, had no effect on performance or water intake.

Weather conditions that corresponded with the weigh dates (days 0-34 and 35-67) and TT observation periods (days 18-22 and 41-46) are presented in Table 3. A heat wave occurred during days 44-46 (Fig. 1) in which the temperature humidity index \{THI; Thom 1959; THI $=.0 .8 \times$ (ambient temperature $)+[(\%$ relative humidity $\div 100) \times$ (ambient temperature -14.4$)]+46.4)\}$ averaged or exceeded 84 for 3 days in a row. A THI of 84 or greater is considered to be in an emergency category, in which cattle are experiencing extreme heat stress (LCI 1970; Mader 2003). Thus, days 41-46 data were analyzed as two 3-day periods (MHOT and HOT), as well as one 6-day period. Initial analyses revealed significant potassium by sodium by time-of-day interactions $(P=0.01)$ and potassium by sodium by period effects $(P=0.02)$ for TT. However, when TT were compared within each hour (Fig. 2), there were no significant differences $(P>0.10)$ among treatments in any given hour. Nevertheless, these interactions may be significant because of the differing daily cycles in TT for the treatments. Namely, Na may result in a lower peak TT

Table 2 Average daily gain (ADG), dry matter feed intake (DMI), and daily water intake (DWI) for cattle fed sodium (Na) and potassium (K)

\begin{tabular}{|c|c|c|c|c|c|c|c|c|}
\hline & \multicolumn{4}{|c|}{ Treatment $^{\mathrm{a}}$} & \multirow[b]{2}{*}{ SEM } & \multicolumn{3}{|c|}{$P$-value } \\
\hline & Control & K & $\mathrm{Na}$ & $\mathrm{KNa}$ & & K & $\mathrm{Na}$ & $\mathrm{K} \times \mathrm{Na}$ \\
\hline ADG (kg) & 1.40 & 1.41 & 1.45 & 1.28 & 0.05 & 0.12 & 0.46 & 0.09 \\
\hline DMI (kg) & 10.38 & 10.27 & 10.24 & 9.34 & 0.22 & 0.26 & 0.20 & 0.51 \\
\hline Gain:feed & 0.134 & 0.136 & 0.141 & 0.129 & 0.005 & 0.33 & 0.99 & 0.19 \\
\hline DWI (L) & 30.4 & 37.1 & 26.8 & 38.0 & 2.8 & 0.01 & 0.60 & 0.42 \\
\hline DWI/DMI & 2.93 & 3.62 & 2.62 & 3.86 & 0.32 & 0.01 & 0.35 & 0.35 \\
\hline
\end{tabular}

${ }^{\mathrm{a}}$ Control = control; $\mathrm{K}$ = potassium bicarbonate added to diet; $\mathrm{Na}=$ sodium chloride added to diet; $\mathrm{KNa}=$ potassium bicarbonate and sodium chloride added to diet 
Table 3 Mean environmental conditions during study and periods tympanic temperatures (TT) were recorded. ${ }^{a} T_{a}$ Ambient temperature, $T H I$ temperature humidity index, $R H$ relative humidity

\begin{tabular}{|c|c|c|c|c|c|c|c|}
\hline & \multicolumn{3}{|c|}{$T_{\mathrm{a}}\left({ }^{\circ} \mathrm{C}\right)$} & \multirow[t]{2}{*}{ RH (\%) } & \multirow[t]{2}{*}{$\mathrm{THI}^{\mathrm{b}}$} & \multirow[t]{2}{*}{ Windspeed $(\mathrm{m} / \mathrm{s})$} & \multirow[t]{2}{*}{ Solar radiation $\left(\mathrm{W} / \mathrm{m}^{2}\right)$} \\
\hline & High & Low & Mean & & & & \\
\hline Days $0-34$ & 28.71 & 16.75 & 22.73 & 71.31 & 70.6 & 4.39 & 269.20 \\
\hline Days 35-67 & 29.82 & 17.13 & 23.47 & 77.06 & 72.2 & 3.24 & 245.82 \\
\hline Days $18-22^{\mathrm{c}}$ & 29.21 & 17.62 & 23.42 & 72.59 & 71.7 & 4.68 & 299.20 \\
\hline Days $41-43^{c}$ & 31.37 & 18.59 & 24.98 & 81.44 & 75.0 & 4.25 & 283.91 \\
\hline Days $44-46^{\mathrm{c}}$ & 34.02 & 22.13 & 28.07 & 75.10 & 79.2 & 3.64 & 280.85 \\
\hline
\end{tabular}

${ }^{a}$ Solar radiation recorded from a weather station located $1.85 \mathrm{~km}$ north and $0.93 \mathrm{~km}$ west of feeding facilities. Other recordings taken from weather station located in the feeding facilities

${ }^{\mathrm{b}}$ Calculated as $\mathrm{THI}=0.8 \times\left(T_{\mathrm{a}}\right)+\left[(\% \mathrm{RH} \div 100) \times\left(T_{\mathrm{a}}-14.4\right)\right]+46.4$

${ }^{\mathrm{c}}$ Weather for periods that correspond to TT recording. Heat stress was denoted as thermoneutral for days 18-22 (TNL), moderately hot days 4143 (MHOT), and hot for days 44-46 (HOT)

and the $\mathrm{K}$ plus $\mathrm{Na}$ combination treatment tended to show TT declining at a faster rate during the late evening hours.

When TT were compared within each period (Table 4), no significant treatment effects $(P>0.10)$ were found. The tendency for the $\mathrm{K}$ and $\mathrm{Na}$ combination treatment group to have a lower TT may be due to the greater DWI found in that group. Also, the addition of $\mathrm{KHCO}_{3}$ increased dietary cation anion difference (DCAD) from below 10 meq to near 30 meq. Increased DCAD levels are generally thought to aid in maintaining body electrolyte balance during hot weather as well as aid in the reduction of acidosis. Low DCAD may induce mild metabolic acidosis (Vagnoni and Oetzel 1998) and this may act as a trigger for more severe acidosis when feedlot cattle are exposed to high heat load. Ross et al. (1994a, b) suggested a dietary electrolyte balance (DEB) value in the range of $15-30 \mathrm{mEq}$ was optimum for growing and finishing beef cattle. The DEB

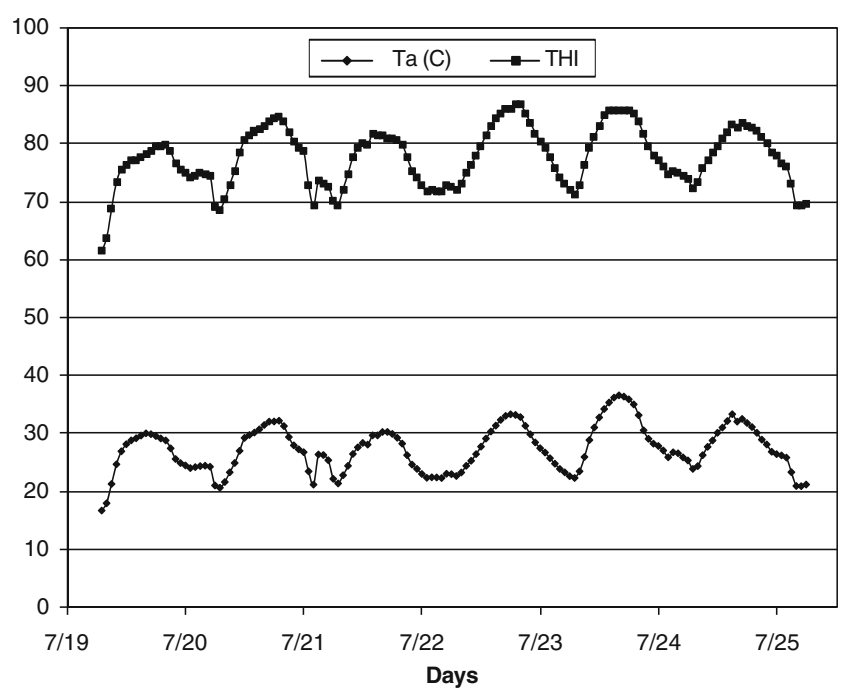

Fig. 1 Ambient temperature $\left(T_{a}\right)$ and temperature humidity index (THI) for days $41-46$ of study does not include $\mathrm{S}$ in the calculation $\{\mathrm{DEB}=\mathrm{Meq}[(\mathrm{Na}+$ $\mathrm{K})-\mathrm{Cl}]\}$ and would tend to be greater than DCAD. The increased water intake could possibly be attributed to the increased DCAD levels. Adding Na to the diet did not influence DCAD due to $\mathrm{Na}$ being added as $\mathrm{NaCl}$ salt.

As a result of no treatment difference being found in TT for $\mathrm{Na}$ and $\mathrm{K}$ supplementation, data from days 41-46 were subsequently analyzed to assess TT profiles of cattle exhibiting high, moderate or low levels (eight head/stress level) of heat stress based on mean TT found over the 6-day period (Table 5; Fig. 3). From these data it is evident that cattle with high TT had elevated TT even during the 1st day (cool day) at 1200 hours and 1700 hours. However, cattle with a moderate TT appeared to have the most elasticity in TT than either the high or low group by reaching moderately high TT during the hot days, but subsequently were able to reach lower $(P<0.05)$ TT at night than either the high (day 0,1 , and 2 ) or the low (day 1 ) group. This could be feed-intake- and possibly performance-related;

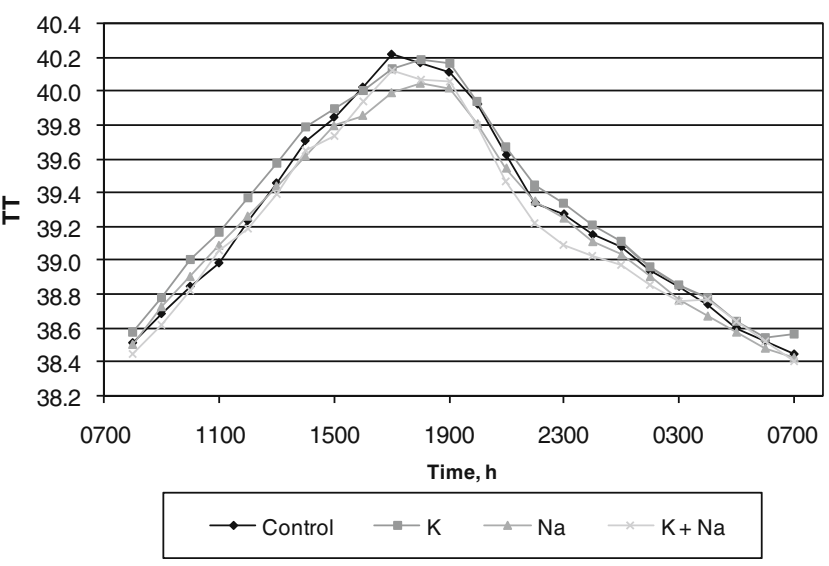

Fig. 2 Effect of potassium $(\mathrm{K})$ and sodium $(\mathrm{Na})$ on hourly tympanic temperature $\left(\mathrm{TT},{ }^{\circ} \mathrm{C}\right)$ averaged over moderately hot and hot periods 
Table 4 Tympanic temperatures within environmental period ${ }^{\mathrm{a}}$

\begin{tabular}{|c|c|c|c|c|c|c|c|c|}
\hline \multirow[b]{2}{*}{ Item } & \multicolumn{5}{|c|}{ Treatment $^{\mathrm{b}}$} & \multicolumn{3}{|c|}{$P$-value } \\
\hline & Control & $\mathrm{K}$ & $\mathrm{Na}$ & $\mathrm{KNa}$ & $\mathrm{SE}$ & $\mathrm{K}$ & $\mathrm{Na}$ & $\mathrm{K} * \mathrm{Na}$ \\
\hline TNL & 39.06 & 39.00 & 38.94 & 38.94 & 0.07 & 0.94 & 0.48 & 0.98 \\
\hline MHOT & 39.06 & 39.06 & 38.94 & 38.94 & 0.08 & 0.86 & 0.26 & 0.97 \\
\hline HOT & 39.67 & 39.67 & 39.72 & 39.56 & 0.11 & 0.41 & 0.86 & 0.55 \\
\hline
\end{tabular}

${ }^{\text {a }}$ Periods: $\mathrm{TNL}=$ thermoneutral; $\mathrm{MHOT}=$ moderately hot; HOT $=$ hot

${ }^{\mathrm{b}} \mathrm{K}=$ potassium bicarbonate added to diet; $\mathrm{Na}=$ sodium chloride added to diet; $\mathrm{KNa}=$ potassium bicarbonate and sodium chloride added to diet

however, over the entire study, the daily gains of the low, moderate, and high TT groups were 1.54, 1.50, and $1.53 \mathrm{~kg} /$ day, respectively, and during the last 32 days of the study, daily gains were $1.04,1.03$, and $0.92 \mathrm{~kg}$ /days, respectively.
It should also be noted that animals from each diet treatment group were represented in each TT profile group with $15-45 \%$ of the animals in a respective diet treatment group also being found in each of the TT profile groups.
Table 5 Daily $\mathrm{TT}$ of cattle exhibiting high, moderate, and low TT during days 41 through 46 of the study. Means within a day and time with different lower case letters differ $(P<0.05)$

\begin{tabular}{|c|c|c|c|c|c|}
\hline & \multicolumn{5}{|c|}{ Cattle TT $\left({ }^{\circ} \mathrm{C}\right)$} \\
\hline & High & Moderate & Low & $\mathrm{SE}$ & $P$-value \\
\hline \multicolumn{6}{|l|}{ Cool day } \\
\hline Minimum & - & - & - & - & \\
\hline Noon & $39.04 \mathrm{a}$ & $38.66 \mathrm{~b}$ & $38.75 \mathrm{~b}$ & 0.10 & 0.04 \\
\hline Maximum (1700 hours) & $39.54 \mathrm{a}$ & $39.02 \mathrm{~b}$ & $39.21 \mathrm{~b}$ & 0.09 & 0.00 \\
\hline Midnight & 39.20 & 38.98 & 38.93 & 0.12 & 0.25 \\
\hline \multicolumn{6}{|l|}{ Day -2} \\
\hline Minimum (0800 hours) & 38.33 & 38.25 & 38.27 & 0.07 & 0.67 \\
\hline Noon & $39.14 \mathrm{a}$ & $38.83 \mathrm{~b}$ & $38.93 \mathrm{ab}$ & 0.08 & 0.04 \\
\hline Maximum (1800 hours) & 40.26 & 39.96 & 39.92 & 0.10 & 0.06 \\
\hline Midnight & 39.10 & 38.88 & 39.02 & 0.07 & 0.15 \\
\hline \multicolumn{6}{|l|}{ Day -1} \\
\hline Minimum (0800 hours) & 38.31 & 38.09 & 38.24 & 0.07 & 0.16 \\
\hline Noon & $39.26 \mathrm{a}$ & $38.79 \mathrm{~b}$ & $38.98 \mathrm{ab}$ & 0.10 & 0.02 \\
\hline Maximum (1700 hours) & $40.30 \mathrm{a}$ & $39.84 \mathrm{~b}$ & $39.80 \mathrm{~b}$ & 0.13 & 0.03 \\
\hline Midnight & 39.06 & 38.82 & 39.02 & 0.95 & 0.21 \\
\hline \multicolumn{6}{|l|}{ Day 0 (start of hottest day) } \\
\hline Minimum (0700 hours) & $38.67 \mathrm{a}$ & $38.30 \mathrm{~b}$ & $38.42 \mathrm{~b}$ & 0.08 & 0.02 \\
\hline Noon & $39.91 \mathrm{a}$ & $39.29 \mathrm{~b}$ & $39.40 \mathrm{~b}$ & 0.06 & $<0.00$ \\
\hline Maximum (1800 hours) & $41.97 \mathrm{a}$ & $41.52 \mathrm{~b}$ & $40.96 \mathrm{c}$ & 0.09 & $<0.00$ \\
\hline Midnight & 39.69 & 39.39 & 39.63 & 0.14 & 0.32 \\
\hline \multicolumn{6}{|l|}{ Day 1} \\
\hline Minimum (0700 hours) & $38.36 \mathrm{a}$ & $38.04 \mathrm{~b}$ & $38.48 \mathrm{a}$ & 0.10 & 0.01 \\
\hline Noon & $40.30 \mathrm{a}$ & $39.76 \mathrm{~b}$ & $39.89 \mathrm{~b}$ & 0.15 & 0.06 \\
\hline Maximum (1700 hours) & $41.33 \mathrm{a}$ & $40.89 \mathrm{~b}$ & $40.75 \mathrm{~b}$ & 0.13 & 0.02 \\
\hline Midnight & $39.44 \mathrm{a}$ & $39.00 \mathrm{~b}$ & $39.07 \mathrm{~b}$ & 0.10 & 0.02 \\
\hline \multicolumn{6}{|l|}{ Day 2} \\
\hline Minimum (0700 hours) & $38.71 \mathrm{a}$ & $38.14 \mathrm{~b}$ & $38.49 \mathrm{a}$ & 0.11 & 0.01 \\
\hline Noon & $40.69 \mathrm{a}$ & $39.89 \mathrm{~b}$ & $40.12 \mathrm{~b}$ & 0.15 & 0.01 \\
\hline Maximum (1500 hours) & $41.49 \mathrm{a}$ & $40.80 \mathrm{~b}$ & $40.88 \mathrm{~b}$ & 0.14 & 0.00 \\
\hline Midnight & $39.43 \mathrm{a}$ & $39.01 \mathrm{~b}$ & $39.32 \mathrm{ab}$ & 0.09 & 0.01 \\
\hline
\end{tabular}




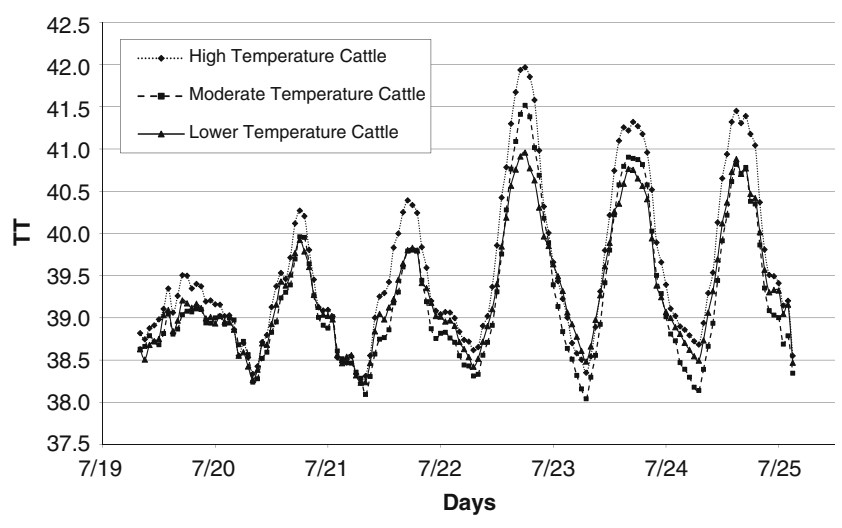

Fig. 3 Tympanic temperature $\left({ }^{\circ} \mathrm{C}\right)$ pattern of cattle exhibiting high, moderate, and low TT during days $41-46$ of feeding study

\section{Discussion}

Whereas new knowledge about animal responses to the environment continues to be developed, managing cattle to reduce the impact of climate remains a challenge (Hahn 1995, 1999; Gaughan et al. 2000; Mader et al. 2006). In particular, additional information is needed to guide managers when making decisions prior to and during periods of adverse weather (Mader 1986; Mader et al. 1997; Brown-Brandl et al. 2005).

Several management strategies exist that may be helpful in reducing the effects of heat stress. Restricting or altering feed intake pattern is one of these strategies. Mader et al. (1999) found that by lowering feed intake, body temperature is reduced; this most likely occurs as a result of maintenance energy requirements being reduced as is overall metabolic heat production. Also, lowering body temperature through sprinkling or by reducing metabolizable energy intake prior to exposure to excessive heat load enhances the ability of cattle to cope under hot environmental conditions (Davis et al. 2003). Manipulation of metabolizable energy intake can be accomplished easily through diet alterations and bunk management programs (Mader et al. 1999, 2001).

In the present study, the combination of $\mathrm{Na}$ and $\mathrm{K}$ tended to lower DMI and overall MEI. These data suggest that overall, the addition of $\mathrm{KHCO}_{3}$ at the $2 \%$ level and/or $\mathrm{NaCl}$ at the $1 \%$ level did not appear to impair or enhance performance or heat stress tolerance using these diet formulations. However, the addition of $\mathrm{KHCO}_{3} \mathrm{did}$ enhance water intake. Also, the combination of $\mathrm{KHCO}_{3}$ and $\mathrm{NaCl}$ tended to depress daily gain. The lack of a positive performance or TT change, particularly in potassium diets, is unclear. Potassium and sodium are the primary cations involved in the maintenance of the blood acid-base chemistry, essentially maintaining blood $\mathrm{pH}$. When cattle are heat stressed, excessive panting increases plasma $\mathrm{pH}$ and bicarbonate, reduces blood buffering capacity, and increases urinary excretion of sodium and bicarbonate ion (Sparke et al. 2001). The $\mathrm{K}$ and $\mathrm{KNa}$ diets had elevated DCAD levels, which may be more important for maintaining blood $\mathrm{pH}$ than individual elements (Escobosa et al. 1984; Wildman et al. 2007; Ross et al. 1994a, b). Reduced DCAD may induce mild metabolic acidosis (Vagnoni and Oetzel 1998), which may result in more severe acidosis when feedlot cattle are exposed to an increased heat load. Because only small amounts of potassium are stored in the body, supplementation may be required during periods of heat stress (NRC 1996). It is thought that potassium carbonates and bicarbonates are better supplements than potassium chloride because increased intake of chlorine has been shown to depress DMI in dairy cows in summer (Sanchez et al. 1994). In the current study, added potassium, sodium, and/or chloride did not appear to have either beneficial or detrimental effects.

Based on TT profiles, these data suggest that cattle that fail to or that do not cool down at night are prone to achieving greater body temperatures during hot days. Cattle that are prone to getting hot but can cool at night can keep peak body temperatures at or near those of cattle that tend to consistently maintain lower body temperatures. Similar findings were reported by Mader et al. (1999), who found that cattle that have the ability and(or) opportunity to dissipate body heat at night tend to have lower peak TT the following day. In the current study, all TT profile groups appeared to show some TT compensation by displaying lower morning TT during the three hot days than they had during the cool day. However, the average magnitude of difference (compensation) was greater for the high $(38.58-$ $\left.39.04=-0.46^{\circ} \mathrm{C}\right)$ and moderate $\left(38.16-38.66=-0.50^{\circ} \mathrm{C}\right)$ profile groups vs the low $\left(38.46-38.75=-0.29^{\circ} \mathrm{C}\right) \mathrm{TT}$ profile group. In addition, during cooler and moderately hot periods, TT of cattle changes in a cyclical or stair-step (up and down) pattern. However, while under hot conditions, TT moves in conjunction with ambient conditions, indicating that thermoregulatory mechanisms are near maximum physiological capacity for preventing TT from rising. It should be noted that these data are based on the average of a group of animals, which tends to smooth the body temperature curve. Individual animals may display a more erratic TT profile pattern.

Tympanic temperatures of cattle exposed to hot conditions in the summer display a greater range than when cattle are exposed to cold conditions in the winter (Mader and Kreikemeier 2006). Maximum TT are greater $(P<0.01)$ and minimum TT are lower $(P<0.01)$ in the summer than in the winter. Also, during hot environmental conditions, TT of dark or black-hided cattle are $0.5^{\circ}$ to $0.8^{\circ} \mathrm{C}$ greater than light or white-hided cattle from mid to late afternoon (Mader et al. 2002). Cattle that are most susceptible to heat stress would therefore be black-hided and cattle being full- 
fed a high-energy diet (Mader 2003). Cattle nearly finished or carrying above average body condition would also be subject to heat stress.

\section{Conclusion}

Data reported herein would suggest that there may be considerable variation in heat stress tolerance among cattle, and that some cattle are more susceptible to heat stress than others but that this tolerance is not necessarily performancerelated.

Nevertheless, cattle are remarkable in their ability to mobilize coping mechanisms when challenged by environmental stressors. Within limits, they can adjust physiologically, behaviorally, and immunologically to minimize adverse consequences. Typically, 3-4 days are required for an animal to attain a level of heat balance that permits acclimation to begin decreasing body temperature (Hahn 1999). Under 3-day heat events, such as found in this study, thermoregulatory processes are unable to maintain a constant TT, thus TT tends to mirror changes in environmental conditions as defined by ambient temperature.

\section{References}

Brown-Brandl TM, Eigenberg RA, Hahn GL, Nienaber JA, Mader TL, Spiers DE, Parkhurst AM (2005) Analyses of thermoregulatory responses of feeder cattle exposed to simulated heat waves. Int J Biometeorol 49:285-296. doi:10.1007/s00484-004-0250-2

Davis MS, Mader TL, Holt SM, Parkhurst AM (2003) Strategies to reduce feedlot cattle heat stress: effects on tympanic temperature. J Anim Sci 81:649-661

Doran BE, Owens FN, Armbruster SL, Schmidt D (1986) Effect of supplemental potassium on summer performance of commercial feedlot steers. 1986 Animal Science Research Report, Oklahoma Agricultural Experiment Station, pp 126-130

Escobosa A, Coppock CE, Rowe LD Jr, Jenkins WL, Gates CE (1984) Effects of dietary sodium bicarbonate and calcium chloride on physiological responses of lactating dairy cows in hot weather. J Dairy Sci 67:574-584

Gaughan JB, Mader TL (2009) Effects of sodium chloride and fat supplementation on finishing steers exposed to hot and cold conditions. J Anim Sci 87:612-621. doi:10.2527/jas.2008-1125

Gaughan JB, Holt SM, Hahn GL, Mader TL (2000) Respiration rateis it a good measure of heat stress in cattle? Asian-Aust J Anim Sci 13:329-332

Granzin BC, Gaughan JB (2002) The effect of sodium chloride supplementation on the milk production of grazing Holstein Friesian cows during summer and autumn in a humid subtropical environment. Anim Feed Sci Technol 96:147-160. doi:10.1016/S0377-8401(01)00322-4

Hahn GL (1995) Environmental influences on feed intake and performance of feedlot cattle. In: Owens FN (ed) Proceedings of symposium: intake by feedlot cattle. Oklahoma State University, Stillwater, pp 207-225
Hahn GL (1999) Dynamic responses of cattle to thermal heat loads. J Anim Sci 77(Suppl. 2):10-20

Hahn GL, Mader TL (1997) Heat waves in relation to thermoregulation, feeding behavior and mortality of feedlot cattle. In: Proceedings of 5th International Livestock Environment Symposium, vol I ASAE SP01-97. ASAE. Minneapolis, MN, pp 563571

Hutcheson DP, Cole NA, McLaren JB (1984) Effects of pretransit diets and post-transit potassium levels for feeder calves. Tex Agric Exp Stn 3758(3830):141-143

Kreikemeier W, Mader T, Davis S, Colling D (2003) Feeding kelp meal in feedlot diets. Nebraska Beef Report MP 80-A, University of Nebraska-Lincoln, pp 39-41

LCI (1970) Patterns of transit losses. Livestock Conservation, Omaha, $\mathrm{NE}$

Mader TL (1986) Effect of environment and shelter on feedlot cattle performance. Proceedings of the international symposium on windbreak technology, Lincoln, NE, pp 187-188

Mader TL (2003) Environmental stress in confined beef cattle. J Anim Sci 81(E. Suppl. 2):E110-E119

Mader TL, Kreikemeier WM (2006) Effects of growth-promoting agents and season on blood metabolites and body temperature in heifers. J Anim Sci 84:1030-1037

Mader TL, Dahlquist JM, Gaughan JB (1997) Wind protection effects and airflow patterns in outside feedlots. J Anim Sci 75:26-36

Mader TL, Gaughan JB, Young BA (1999) Feedlot diet roughage level of Hereford cattle exposed to excessive heat load. Prof Anim Sci 15:53-62

Mader TL, Davis MS, Dahlquist JM, Parkhurst AM (2001) Switching feedlot dietary fiber level for cattle fed in winter. Prof Anim Sci 17:183-190

Mader TL, Holt SM, Hahn GL, Davis MS, Spiers DE (2002) Feeding strategies for managing heat load in feedlot cattle. J Anim Sci 80:2373-2382

Mader TL, Davis SM, Kreikemeier WM (2005) Case study: tympanic temperature and behavior associated with moving feedlot cattle. Prof Anim Sci 21:339-344

Mader TL, Davis MS, Brown-Brandl T (2006) Environmental factors influencing heat stress in feedlot cattle. J Anim Sci 84:712-719

NRC (1996) Nutrient requirements of beef cattle, 7th edn. National Academic, Washington, DC

Ross JG, Spears JW, Garlich JD (1994a) Dietary electrolyte balance effects on performance and metabolic characteristics in finishing steers. J Anim Sci 72:1600-1607

Ross JG, Spears JW, Garlich JD (1994b) Dietary electrolyte balance effects on performance and metabolic characteristics in growing steers. J Anim Sci 72:1842-1848

Sanchez WK, McGuire MA, Beede DK (1994) Macro-mineral nutrition by heat stress interactions in dairy cattle: review and original research. J Dairy Sci 77:2051-2079

Sparke EJ, Young BA, Gaughan JB, Holt SM, Goodwin PJ (2001) Heat load in feedlot cattle. MLA Project FLOT.307. 308. 309. Meat and Livestock Australia, North Sydney

Spears JW, Harvey RW (1987) Lasalocid and dietary sodium and potassium effects on mineral metabolism, ruminal volatile fatty acids and performance of finishing steers. J Anim Sci 65:830-840

Thom EC (1959) The discomfort index. Weatherwise 12:57-60

Vagnoni DB, Oetzel GR (1998) Effects of dietary cation-anion difference on the acid base status of dairy cows. J Dairy Sci $81: 1643-1652$

Wildman CD, West JW, Bernard JK (2007) Effect of dietary cationanion difference and dietary crude protein on performance of lactating dairy cows during hot weather. J Dairy Sci 90:18421850. doi: $10.3168 /$ jds.2006-546 